\title{
KEPASTIAN HUKUM PAYMENT GUARANTEE PADA KONTRAK PERBANKAN DENGAN DEVELOPER
}

\author{
Siti Nurwullan, Hendrik Fasco Siregar, Frieda Fania \\ Fakultas Hukum Universitas Pamulang \\ E-Mail : Wulancitra228@gmail.com
}

\begin{abstract}
Abstrak
Payment Guarantee atau pembelian kembali jaminan kredit memitigasi resiko Bank dalam hal Debitur macet pembayarannya, yang tertuang dalam Perjanjian Kerjasama Bank dengan Developer sebagai penjamin Debitur disebabkan karena dalam Perjanjian Kerjasama Bank tidak bisa mengeksekusi jaminan dikarenakan belum ada Akta Jual Beli (AJB) dan objek jaminan belum atas nama Debitur. Tujuan dari penelitian ini untuk mengetahui bentuk kepastian hukum Payment Guarantee bagi Perbankan sebagai Penyalur kredit. Metode Penelitian yang digunakan yuridis empiris, analisa bahan hukum yang dipakai adalah dengan cara yuridis kualitatif dengan penguatan pada bahan hukum yang diperoleh dilapangan. Hasil penelitian menyimpulkan bahwa Bank Sebagai lembaga penyalur kredit selalu dihadapkan pada resiko. Dan untuk memitigasi resiko tersebut adalah dengan adanya jaminan pembelian kembali (Payment Guarantee) yang diatur dalam Perjanjian Kerjasama yang memberikan kepastian hukum antara pihak Bank dan Developer sebagai penjamin Debitur.
\end{abstract}

Kata Kunci: kreditur; jaminan; kontrak; pembelian.

\begin{abstract}
Payment Guarantee or repurchase of credit guarantees mitigates the risk of the Bank in the event the Debtor defaults on payment, which is stated in the Cooperation Agreement between the Bank and the Development as the Debtor guarantor because in the Cooperation Agreement the Bank can not execute the guarantee because there is no sale and purchase Deed (AJB) and the guarantee object has not yet on behalf of the Debtor. The purpose of this study is to determine the form of legal certainty for the Payment Guarantee for Banks as Credit Lenders. The research method used is juridical empirical method with strengthening of legal materials obtained in the field. The results of the study conclude that the bank as a credit channeling institution is always faced with risks. And to mitigate this risk is the existence of a repurchase guarentee (Payment Guarantee) which is regulated in the Cooperation Agreement which
\end{abstract}


provides legal certainty between the Bank and the Developer as guarantor for the Debtor.

Keywords: creditors; guarantee; contract; purchase.

\section{Pendahuluan}

Sandang, pangan dan papan begitu pokok untuk kehidupan manusia sepanjang masa, ketiganya sangat dibutuhkan oleh manusia dalam menunjang kehidupannya. Dewasa ini kebutuhan manusia tidak lagi hanya terbatas memenuhi sisi sandang dan pangan saja, melainkan masyarakat mulai berlomba-lomba memenuhi sisi papan sebagai alat ukur kesejahteraan hidupnya juga. Papan sebagai istilah dari pada rumah seperti sulit untuk dijangkau bagi sebagian masyarakat menengah ke bawah. Oleh sebab itu berdasarkan kebutuhan atas papan tersebut di atas merupakan peluang usaha atau bisnis bagi sebagian Pengusaha property atau Developer untuk membantu pihak Konsumen yang menginginkan sebuah rumah tapi tidak bisa membeli secara kontan.

Banyak solusi yang ditawarkan oleh para pelaku usaha property dan Perbankan, salah satunya bisa memiliki rumah melalui KPR (Kredit Pemilikan Rumah), namun banyak syarat yang harus dipenuhi oleh pihak Pengaju atau Konsumen.Secara spesifik karakter bisnis Perbankan sebagai penyalur kredit bagi rakyat dan pelaku usaha tidak akan lepas dari pasal 1320 KUHPerdata dalam menjalankan aktifitas usahanya tetapi selain itu Perbankan memiliki landasan hukumdalam setiap gerak langkahnya melalui Undang-Undang Perbankan dan aturan lainnya, kondisi ini memberikan sifat kekhususan tersendiri Bagi Perbankan ketika akan melakukan kerjasama atau berkontrak. ${ }^{1}$

Faktual dan actual setelah syarat-syarat yang diminta terpenuhi konsumen tidak serta merta pengajuan KPR disetujui oleh pihak Bank sebagai lembaga pembiayaan, terdapat beberapa aturan yang harus dipenuhi oleh Konsumen dan pihak Developer terkait syarat-syarat tertentu ataupun aturan dari pihak Bank yang harus dipenuhi dan tercantum dalam kontrak antara pihak Bank dengan pihak Developer serta pihak Konsumen. Salah satu faktor penunjang dan menjadi andalan agar proses pengajuan kredit dan kerjasama dapat berjalan lancar baik pihak Developer dan pihak Perbankan menawarkan instrument Payment Guarantee dalam kontrak kerjasama yang akan dibuat.

${ }^{1}$ Siti Nurwullan, Hendrik Fasco Siregar, Frieda Fania, Aspek Yuridis Perbankan sebagai Penyalur Kredit Persfektif Asas Konsesnsualime Dalam Berkontrak, Jurnal Pamulang Law Review,3.8 (2020) hlm. 39. 
Payment Guarantee atau Buyback Guarantee adalah istilah bahasa Inggris yang secara harfiah berarti jaminan membeli kembali. Sejauh ini tidak ada literature atau referensi yang menulis tentang pertama kalinya penggunaan istilah Buyback Guarantee untuk mengartikan atau jaminan dari pengembang atas kredit yang diterima oleh Konsumen/Debitur dari Bank dalam perjanjian kerjasama pemberian fasilitas kredit pemilikan rumah di Indonesia. Buyback Guarantee sangat erat kaitannya dengan kredit pemilikan rumah. ${ }^{2}$

Substansi Payment Guarantee atau Buyback Guarantee dari jaminan membeli kembali oleh Developer adalah membeli kembali aset yang sudah di jual oleh Developer kepada Konsumen yang hubungan hukumnya adalah antara Bank dengan Developer; Antara Bank dengan Debitur; dan antara Developer dengan Konsumen. Jadi hubungan hukumnya seperti itu. ${ }^{3}$

Ketika pihak Konsumen mengalami gagal bayar atau wanprestasi dan juga Developer tidak dapat melakukan Payment Guarantee yang telah disetujui dalam kontrak kerjasama dengan pihak Perbankan maka akan berakibat macetnya kredit sehingga merugikan pihak Perbankan dan Developer, dan menurut hemat penulis ini penting dan sangat urgent untuk diteliti dan dikaji karena resiko kerugian terbesar dari ketiga pihak tersebut berada di pihak Perbankan sebagai lembaga penyalur kredit yang akan berdampak pada perekomian secara meluas.

\section{Rumusan Masalah}

Berdasarkan latar belakang yang diuraikan di atas, maka penulis merumuskan masalah sebagai berikut Pertama, apakah motivasi Perbankan menggunakan Payment Guarantee dalam Perjanjian Kerjasama dengan Developer ?, kedua, Bagaimana bentuk kepastian hukum Payment Guarantee dalam Perjanjian Kerjasama antara Bank dengan Developer?

\section{Metode Penelitian}

Penelitian di fokuskan pada wilayah kabupaten Tangerang Selatan, merupakan salah satu Kota Provinsi Banten. Pemilihan lokasi di Kabupaten Tangerang Selatan dengan mempertimbangkan Pergerakan bisnis property yang dilakukan Developer yang melibatkan dunia Perbankan. Payment Guarantee sebagai instrument dalam Perjanjian Kerjasama antara Bank dengan Developer memiliki peran yang penting dalam memitigasi resiko kerugian pada Bank

${ }^{2}$ Yandri Radhi Anadi, Kekuatan Hukum Akta Buy Back Guarantee Dengan Kuasa Menjual Bagi Pihak Developer, Jurnal Hukum dan Kenotariatan,31,2,2019.

${ }^{3}$ Wawancara dengan DR. Akhmad Budi Cahyono,S.H.,M.H. , Dosen Hukum Perdata Universitas Indonesia , Kamis, 16 Juli 2020. 
sebagai penyalur kredit dalam Perjanjian Kerjasama antara Bank dengan pihak Developer.

Bahan hukum yang dipakai dalam penelitian ini, adalah bahan sekunder (secondary data) dan bahan primer (primary data). Bahan hukum sekunder merupakan bahan dari penelitian kepustakaan dan dokumen, yang merupakan hasil penelitian dan pengolahan orang lain,dan telah tersedia dalam bentuk buku-buku atau dokumen yang biasanya disediakan di perpustakaan, atau koleksi pribadi. Bahan hukum primer merupakan bahan yang diperoleh langsung dari lapangan. Sedangkan bahan Hukum sekunder mencakup bahan hukum primer, bahan hukum sekunder, dan bahan hukum tertier. Data sekunder yang digunakan dalam penelitian ini, yaitu terdiri dari UndangUndang,ketentuan hukum yang masih berlaku dan terkait.

Metode pengumpulan bahan hukum yang digunakan dalam penelitian ini meliputi kepustakaan; wawancara (interview), pengamatan (observasi), Sesuai dengan sumber bahannya, maka dalam penelitian ini pengumpulan data dilakukan dengan cara : Studi Kepustakaan, yaitu dengan mencari dan mengumpulkan serta mengkaji peraturan perundang-undangan, rancangan undang-undang, hasil penelitian, jurnal ilmiah, artikel ilmiah, dan makalahmakalah seminar yang berhubungan dengan kajian-kajian kepastian hukum Payment Guarantee.

Teknik Wawancara (interview) Terhadap bahan hukum dilapangan dikumpulkan dengan teknik wawancara yaitu dengan mengadakan komunikasi langsung kepada informan, dengan menggunakan pedoman wawancara (interview guide) guna mencari jawaban atas persoalanpelaksanaan Payment Guarantee dan kepastian hukumnya.

Metode analisa data yang digunakan dengan cara data yang diperoleh baik dari studi kepustakaan maupun dari penelitian lapangan akan dianalisis secara deskriptif kualitatif kemudian dihubungkan dengan teori-teori, asasasas,dokrin dan kaidah-kaidah hukum yang diperoleh dari studi kepustakaan sehingga diperoleh jawaban atas permasalahan yang dipersoalkan.

\section{Pembahasan}

\section{Payment Guarantee dan Prinsip Kehati-hatian Berkontrak}

Kontrak atau Perjanjian Kerjasama adalah bukti atau dokumen tertulis yang menunjukkan adanya keinginan dan kemauan dari dua pihak atau lebih yang berkepentingan untuk berkolaborasi dalam kerjasama yang yang dituangkan dalam kontrak dan biasanya kontrak tersebut berisi deskripsi dari sebuah projek yang akan dilakukan disertai dengan bentuk kontribusi masingmasing pihak yang dituangkan dalam klausula perjanjian. 
Secara substansial berkontrak dapat diartikan sebagai peristiwa di mana seseorang atau lebih berjanji kepada orang lain di mana dua orang saling berjanji untuk melaksanakan sesuatu dengan itikad baik, lebih konkrit berkontrak atau membuat perjanjian merupakan satu atau serangkaian janji yang dibuat para pihak dan esensi dari kontrak itu sendiri adalah perjanjian (agreement) dengan itikad baik. ${ }^{4}$

Penting setiap butir kata dalam dokumen kesepakatan kerja sama tersebut untuk diperhatikan pihak Bank dan Developer, hal ini menjadi relevan dikarenakan jika kontrak itu sudah ditandatangani maka akibat hukumnya para pihak harus berkontribusi sesuai dengan kesepakatan tertulis dalam Perjanjian Kerjasama tersebut. Perjanjian merupakan perikatan atau konsensus dalam suatu kondisi hukum yang mengikat satu atau lebih subjek hukum dengan hak dan kewajiban timbal-balik yang berkaitan satu sama lain. Perikatan-perikatan serupa itu memang bisa lahir dari kesepakatan antara dua pihak atau lebih, atau karena Undang-Undang. ${ }^{5}$

Perjanjian Kerjasama hendaknya dapat mendefinisikan pihak-pihak yang terlibat, apa tugas masing-masing pihak, serta tentang tujuan bersama yang ingin di capai. Faktual perjanjian dibuat untuk sebuah kesepakatan dalam jangka waktu tertentu dengan perkiraan akhir masa berlaku perjanjian tersebut. Secara klasik bila di kaji dalam buku ke III KUH Perdata tidak terdapat ketentuan spesifik yang mengatur tentang Perjanjian Kredit, tetapi berdasarkan asas kebebasan berkontrak Perjanjian Kredit dapat dipahami merupakan perjanjian konsensual antara Debitur dan Kreditur (dalam hal ini Bank) yang melahirkan hubungan hutang-piutang, yang mengatur Debitur berkewajiban untuk membayar kembali pinjaman yang diberikan oleh Kreditur dengan berdasarkan syarat dan kondisi serta ketentuan yang telah disepakati oleh para pihak.

Pada asasnya Perjanjian Kredit merupakan merupakan bentuk perikatan kontraktual, sehingga menurut hemat penulis berlakulah ketentuan-ketentuan hukum privat yang tunduk pada ketentuan hukum perjanjian yang ada di dalam Kitab Undang-undang Hukum Perdata Buku III. Sumber hukum Perjanjian Kredit dapat ditinjau pada Undang-Undang Nomor 7 Tahun 1992 sebagaimana telah di ubah dengan ketentuan Undang-Undang Nomor 10 Tahun 1998 tentang Perbankan, undang-undang ini merupakan perwujudan dari asasLex specialis, sedangkan Lex Generalisnya bertumpu pada KUHPerdata Bab XII tentang pinjam-meminjam, juga dapat dilihat pada Bab I sampai dengan bab IV tentang

${ }^{4}$ SitiNurwullan, and Hendrik Fasco Siregar. "Asas Konsensualisme Dalam Penambahan Klausula Kontrak Berdasarkan Prinsip Itikad Baik." PROCEEDINGS. Vol. 1. No. 1. 2020.hlm.497.

${ }^{5}$ Budiono Kusumo hamidjojo, Perbandingan Hukum Kontrak, Mandar Maju, Bandung, 2019, hlm.13. 
ketentuan umum dan konsep ini merupakan dasar formil legalitasnya. Legalitas dan legisme adalah dua gagasan yang mengklaim dapat memberikan kepastian hukum. Namun polemik akan gagasan kepastian hukum dalam penegakan hukum ini sesungguhnya telah dipersoalkan oleh banyak pihak. ${ }^{6}$

Dalam lalu lintas bisnis dan keperdataan kontrak atau Perjanjian Kredit terkadang masih dipahami secara rancu. Banyak pelaku bisnis mencapuradukkan kedua istilah tersebut seolah merupakan pengertian yang berbeda. Dalam BW (Burgerlijk Wetboek) menggunakan istilah overeenkomst dan contact untuk pengertian yang sama. Hal ini secara jelas dapat disimak dari judul buku III titel ke dua tentang "Perikatan-perikatan yang lahir dari kontrak atau perjanjian" yang dalam bahasa aslinya (Belanda), yaitu : "Van verbintenissen die uit contract of overeenkoms geboren worden", yaitu istilah kontrak dan perjanjian dalam pengertian yang sama. Sementara Subekti mempunyai pendapat yang berbeda mengenai istilah "perjanjian atau persetujuan" dengan "kontrak", istilah kontrak baik dalam praktek dan akademis mempunyai pengertian lebih sempit karena ditujukan kepada perjanjian atau persetujuan yang tertulis. Sedangkan kontrak adalah perjanjian yang mengharapkan terlaksananya perikatan. ${ }^{7}$

Bercermin pada ketentuan yang terdapat dalam Pasal 1313 KUHPerdata, aturan ini memberikan definis substansial terhadap pengertian Perjanjian yang merupakan perbuatan hukum dengan akibat hukum yaitu peristiwa hukum satu orang atau lebih dengan sadar mengikatkan dirinya terhadap satu orang lain atau lebih. Berdasarkan peristiwa hukum ini timbullah hubungan hukum antara dua orang atau lebih yang disebut perikatan yang di dalamnya mengatur hak dan kewajiban masing-masing pihak.

Pendapat spesifik dari Sutan Remy Sjahdeini, pencantuman kata-kata persetujuan atau kesepakatan pinjam meminjam didalam pengertian kredit sebagaimana dimaksud dalam UUP (Undang-undang Perbankan) dapat mempunyai beberapa maksud yakni: Pembentuk undang-undang bermaksud untuk menegaskan bahwa hubungan kredit bank adalah hubungan kontraktual antara bank dan nasabah debitur yang berbentuk pinjam-meminjam; Pembentuk undang-undang bermaksud untuk mengharuskan hubungan kredit bank dibuat berdasarkan perjanjian tertulis. ${ }^{8}$

${ }^{6}$ E.FernandoM.Manullang, Legisme,Legalitas dan Kepastian Hukum, Prenada media, Jakarta 2019.hlm.16.

${ }^{7}$ Agus Yudha Hernoko, Hukum Perjanjian Asas Proporsionalitas dalam Kontrak Komersial, Prenada media Group, Jakarta,2014, hlm.13-14.

${ }^{8}$ Sentosa Sembiring, Hukum Perbankan Edisi Revisi,Mandar Maju,Bandung,2012, hlm. 191-192. 
Menurut hemat penulis dan berpijak pada pandangan ahli di atas akan tampak hubungan hukum antara badan usaha Bank (Kreditur) dan Nasabah (Debitur) diikat oleh suatu perjanjian tertulis. Ketika Perjanjian tertulis antara Kreditur dan Debitur ditelah ditandatangani para pihak, tetapi harus diketahui pada umumnya perjanjian ini terkadang sudah dalam bentuk kontrak standar namun walau demikian menurut penulis Perjanjian Kredit tersebut hendaknya dipelajari lebih rinci dan teliti karena implikasi dan akibat hukum yang muncul sebagai akibat ditandatanganinya suatu perjanjian maka para pihak berkewajiban untuk mematuhinya.

Para pihak yang akan mendatangani suatu Perjanjian Kredit hendaknya meneliti dengan dengan cermat terkait hak dan kewajiban yang harus dipenuhi jika Perjanjian Kredit sudah ditandatangani. Hal ini sangat urgent mengingat dalam Perjanjian Kredit sarat dengan klausul yang dituangkan dengan bahasa hukum multi interpretasi. Artinya ada sejumlah persyaratan yang harus dipatuhi oleh Debitur, apabila tidak maka akan berakibat atau memiliki konsekuensi diantaranya berupa denda dan bunga yang tentunya dapat merugikan pihak Debitur.

Bank dalam menjalankan aktivitas usahanya menghadapi berbagai risiko dan diantara resiko tersebut adalah risiko kredit (credit risk) dari suatu Perjanjian Kredit, resiko yang akan dialami yakni ketidakpastian tentang pembayaran kembali pinjaman Debitor, dan risiko yang berhubungan dengan manajemen yakni risiko yang timbul karena kekurangcakapan dalam segi manajemen. Risiko dalam bisnis Perbankan adalah sesuatu yang alamiah (natural) dan selalu akan dihadapi Bank. Risiko dalam menyalurkan kredit yang terutama bagi Bank adalah kredit menjadi macet dalam arti Bank tidak lagi, atau tidak teratur dalam menerima bunga dan angsuran pelunasan kredit. Hal ini tentu saja akan merugikan Bank karena akan mendapatkan kerugian.

Sebagai perbandingan dalam penyaluran kredit dapat dilihat konsep pemberian kredit dengan prinsip Syariah sebagaimana dimaksud pada UndangUndang Nomor 10 tahun 1998 tentang Perbankan dalam pasal 8 menyebutkan bahwa dalam memberikan kredit berdasarkan prinsip syariah, Bank umum wajib mempunyai keyakinan berdasarkan analisis yang mendalam atas itikad baik dan kemampuan serta kesanggupan Nasabah Debitur untuk melunasi hutangnya. ${ }^{9}$ Pada umumnya dalam standard operasional Perbankan guna meminimalisir resiko penyaluran kredit yang mungkin saja terjadi, Bank pada umumnya akan sangat berhati-hati dan profesional dalam penyaluran kredit, biasanya Bank menggunakan cara dan rumusan $5 \mathrm{C}$ atau The five C's dalam memutuskan 
kelayakan pemberian kredit, hal ini akan terkait dengan pertanyaan apakah kredit yang diajukan oleh Pemohon diterima atau ditolak yakni diantaranya; Sifat atau karakter Pemohon merupakan salah satu fokus dari Bank yang akan menganalisa data pemohon kredit yang telah disediakan oleh Bank. Untuk menyakinkan Bank biasanya perlu diadakan wawancara, untuk mengetahui lebih rinci, bagaimana karakter yang sesungguhnya dari calon debitor.

Kemampuan atau kapasitas Pemohon merupakan fokus Bank dengan cara melihat sumber penghasilan dari pemohon dihubungkan dengan pemenuhan kebutuhan sehari-hari,dan Bank dapat menganalisa permohonan yang diajukan rasional atau sesuai kemampuan yang ada pada Debitor sendiri.

Permodalan dari atau Capital Pemohon, mendapatkan perhatian Bank karena hal ini cukup penting yaitu dengan mengkaji ulang potensi dari modal yang ada, khususnya untuk kredit yang cukup besar.

Jaminan atau Collateral debitor perlu di kaji okeh pihak Bank yaitu terkait pertanyaan apakah jaminan yang diberikan oleh Debitor sebanding dengan kredit yang diminta, dan menurut Bank hal ini penting agar bila Debitor tidak mampu melunasi kreditnya jaminan dapat dijual guna melunasi kewajiban Debitor. Terkait jaminan umum merupakan yang merupakan kaidah hukum yang menata tentang jaminan bagi setiap kreditor terkait kebendaan milik debitur atas Utang-utangnya. Pemahaman kata "umum" dalam hal itu bisa ditujukan terhadap semua benda-benda milik Debitur (tanpa kecuali) sebagai jaminan utang-utangnya, bisa juga ditujujan terhadap semua kreditor-kreditor Debitur tersebut. ${ }^{10}$

Condition of economi (kondisi ekonomi) Pemohon Kredit atau pinjaman, situasi dan kondisi eknomi apakah memungkinkan untuk itu. Selain menggunakan 5C dalam berbagai kepustakaan hukum perbankan juga dikemukakan perlu memperhatikan aspek lainnya. Apabila semua instrumen dalam menganalisis kredit dijalankan sepenuhnya, secara teoritis bagi Bank, kredit yang diberikan relatif cukup aman. Dengan kata lain, kredit akan lunas sesuai dengan kesepakatan.

Sebagaimana diketahui selama ini terkait jaminan (collateral) ada yang bersifat kebendaan, dan bersifat perorangan dapat berupa penjamin hutang atau borgtocht (personal guarantee), jaminan perusahaan (Corporate guarantee), perikatan Tanggung menanggung, dan garansi bank (Bank guarantee). ${ }^{11}$

${ }^{10} \mathrm{I}$. Ketut Oka Setiawan, Hukum Pendaftaran Tanah dan Hak Tanggungan, Sinar Grafika, Jakarta,2019, hlm.85.

${ }^{11}$ Racmadi Usman, Hukum Jaminan Keperdataan, Sinar Grafika,Jakarta, 2016, hlm. 76. 
Terkait bentuk jaminan (collateral) kebendaan, dan bersifat perorangan, secara tersirat dalam Peraturan Bank Indonesia Nomor 17/10/PBI/2015 yang menjelaskan ketentuan mengenai pembiayaan perkreditan menjelaskan pentingnya instrument Payment Guarantee sebagaimana dapat dilihat dalam prinsip kerjasama yang bersumber pada pasal 15 ayat (2) huruf (b) dan huruf (c) yang pada intinya menjelaskan perlunya perjanjian kerjasama antara bank dan developer yang memuat kesanggupannya untuk menyelesaikan pembangunan atau pekerjaan sesuai dengan yang diperjanjikan, dijelaskan selanjutnya terdapat harus ada jaminan kepada Bank yang diberikan oleh pengembang baik yang berasal dari pengembang atau developer sendiri atau pihak lain yang dapat digunakan untuk nantinya menyelesaikan kewajiban pengembang apabila property atau pembangunan tidak dapat diselesaikan dan/atau tidak dapat diserahkan sesuai dengan apa yang di perjanjian dalam kontrak.

Perlu dipahami ada berbagai bentuk Jaminan yang diberikan oleh Pengembang kepada Bank baik yang berasal dari Pengembang sendiri atau pihak lain yang dapat digunakan untuk menyelesaikan kewajiban pengembang apabila property tidak dapat diselesaikan dan/atau tidak dapat diserahkan sesuai perjanjian, dan salah satu jaminan tersebut menurut hemat penulis adalah adalah Payment Guarantee atau Buyback Guarantee, yang secara general umumnya memakai istilah Buyback Guarantee walaupun sebagian orang memakai istilah Payment Guarantee, pemakaian istilah Payment Guarantee dapat dibenarkan karena kepemilikan belum beralih, Hak milik belum beralih dan masih atas nama Developer.

Buyback Guarantee merupakan istilah umum yang biasa di pakai dalam perjanjian kredit maupun perjanjian kerjasama. Buyback Gurantee tidak ada dasar hukumnya dan merupakan kebiasaan dalam mekanisme kerjasama dan dasar hukumnya perjanjian saja. Secara konsepsual dan secara hukum Payment Guarantee ada dasar hukumnya yaitu termasuk konsep penanggungan hutang walaupun konsep penanggungan hutang yang dimaksud disini berbeda dengan Payment Guarantee.

Kontruksi Instrument Payment Guarantee digunakan baik pihak Bank dan Developer karena hak yang diperjanjikan belum beralih, belum ada penyerahan atau levering. Dalam perjanjian objek Payment Guarantee berkaitannya dengan benda tetap, intinya Payment Guarantee digunakan sebagai kesepakatan untuk melunasi kewajiban Konsumen dengan teknis pihak Developer melakukan pembelian kembali dari pihak Bank dan mengambil alih objek jual belinya yang masih berbentuk PPJB (Perjanjian Pengikatan Jual Beli). 


\section{Aspek Yuridis Jaminan Terkait Instrument Payment Guarantee}

Pengaturan dan dasar hukum perjanjian kredit, serta Pranata hukum yang mengatur pinjam-meminjam atau perkreditansecara subtansial diatur dalam buku III Bab XIII KUHPerdata. Konsekuansi logis dan rasio hukum pinjam meminjam secara explisiy dijelaskan dalampasal 1754 KUHperdata, pinjammeminjam merupakan persetujuan dengan mana pihak yang satu memberikan kepada pihak yang lain suatu jumlah barang-barang tertentu yang dimungkinkan dihabiskan karena pemakaian dan lainnya dengan ketentuan bahwa pihak yang menggunakan akan mengembalikan sejumlah yang sama dari jenis dan atau keadaan yang sama pula.

Unsur-unsur Pinjam-meminjam. Dari pemahaman diatas menurut Sentosa Sembiring dalam bukunya Hukum Perbankan Edisi Revisi (2000:191) dapat disimpulkan bahwa unsur-unsur pinjam-meminjam adalah : ${ }^{12}$ Adanya persetujuan antara peminjam dengan yang memberi pinjaman; Adanya suatu jumlah barang tertentu habis karena memberi pinjaman; Pihak yang menerima pinjaman akan mengganti barang yang sama; Peminjam wajib membayar bunga bila diperjanjikan.

Kontrak atau Perjanjian pada asasnya merupakan rangkaian kata sepakat serta akumulasi petemuan atau peresuaian kehendak antara para pihak di dalam perjanjian yang dikehendaki. Intisari dari terminologi kesepakatan yaitu dapat dimaknai ketika Seseorang dapat dinyatakan memberikan persetujuan atau kesepakatan jika memang ia menghendaki apa yang disepakati bersama. Bertolak pada terminologi kata sepakat maka agar supaya perjanjian menjadi sah para pihak hendaknya menyetujui terkait segala hal yang terdapat dalam perjanjian dan hal ini merupakan akumulasi dari fungsi Perjanjian Kredit yang digambarkan sebagai perjanjian pokok, artinya Perjanjian Kredit merupakan sesuatu yang menentukan batal atau tidaknya perjanjian-perjanjian lain yang mengikutinya; dan kesepakatan ini nantinya sebagai alat bukti mengenai batasbatas hak dan kewajiban antara Kreditur dan Debitur dan sebagai alat untuk memonitoring Perjanjian Kredit tersebut.

Walaupun sepakat sebagai persyaratan kehendak yang disetujui antar pihak, tetapi pada kenyataanya walaupun kesepakatan merupakan suatu kehendak yang secara sadar untuk melaksanakan kesepakatan tetapi pada kenyataanya dalam Perjanjian Kerjasama atau Perjanjian Kredit beberapa Developer gagal Payment Guarantee atau membeli kembali objek jual belinya dan hal ini di sebabkan karena ada dua faktor yaitu yang mempengaruhi yaitu terkait Faktor internal dan faktor eksternal.

12Sentosa Sembiring, Op.Cit., hlm. 191. 
Faktor internal akan berpengaruh disebabkan karena Developer tidak memiliki/ mempunyai kemampuan untuk menyelesaikan pembangunan tersebut. Hal ini dapat disebabkan karena Developer tidak jujur terkait badan hukumnya, dan dikarenakan Developer tidak mempunyai pengalaman, dapat pula Konsumen kecewa karena progres pembangunan tidak sesuai sesuai ekspetasi yang di harapkan oleh Konsumen.

Faktor kedua adalah Faktor eksternal yaitu terkait kondisi alam seperti Kondisi ekonomi akibat covid-19 saat sekarang. Berkaca dari kedua faktor yang menyebabkan Developer tidak bisa menjalankan kewajiban untuk membeli kembali objek jual belinya, sehingga kedua factor tersebut harus di antisipasi atau dimitigasi oleh pihak Perbankan.

Faktor eksternal dan internal yang menyebabkan Developer tidak bisa menjalankan kewajiban untuk membeli kembali objek jual belinya maka secara teoritis dan dalam rangka antisipasi maka dalam konsep perjanjian hak perseorangan sangat tergantung dari itikad baik para pihak, berdasarkan hal ini menurut hemat penulis kedepannya harus ada ketentuan khusus yang mengatur mengenai perjanjian Payment Guarantee atau Buyback Guarantee, apabila dibandingkan misalnya dengan negara-negara yang memiliki konsep secure transection atau transaksi berjamin, dalam transaksi berjamin memiliki pengertian yang sangat luas sekali jadi setiap transaksi yang diikat dengan jaminan itu di atur dalam aturan ini, sementara dalam hukum kita yang di atur hanya jaminan kebendaan saja jadi untuk kedepanya harapan penulis agar kita dapat mengikuti konsep yang ada di negara Common Law. Konsep transaksi berjamin memiliki postulat yaitu semua jenis transaksi bisnis yang di ikat oleh jaminan telah diatur dalam transaksi tersebut, sementara dalam hukum perdata yang atur baru jaminan kebendaan saja selebihnya di atur pada kebebasan para pihak yaitu dalam konsep kebebasan berkontrak.

Konsep yang berpedoman pada konsep kebebasan berkontrak belum memberikan kepastian hukum, dan apabila semua jaminan yang ada sudah di atur oleh undang-undang terutama mekanisme eksekusi jaminan tersebut akan sangat membantu dalam penyelesaian sengketa dikemudian hari, misalnya tentang jaminan yang didasarkan pada perjanjian atau perorangan ketika Developer wanprestasi dan tidak bisa menggunakan mekanisme eksekusi, artinya harus melalui gugatan biasa ini akan sangat memerlukan waktu cukup panjang dan seandainya bisa di atur dalam undang-undang maka dapat langsung dilakukan eksekusi terhadap aset-aset Developer sehingga lebih menjamin kepastian hukum.

Dalam Perjanjian Kerjasama antara Bank dengan Developer instrumen Payment Guarantee sangat bermanfaat karena dengan adanya jaminan pembelian kembali setidaknya ada ikatan antar pihak Bank dan Developer 
terkait dengan objek jual belinya, justru apabila tidak ada Payment Guarantee kerja sama tersebut kurang memberikan kepastian hukum. Ikatan secara khusus antara Bank dan Developer dalam Perjanjian Kerjasama, Payment Guarantee lebih memberikan kepastian hukum di bandingkan apabila tidak dicantumkan dalam klusula perjanjian.

Resiko kerugian kredit macet pihak Perbankan dalam kondisi ekonomi secara makro saat ini yang disebabkan karena bencana seperti pandemic covid19 yang dialami saat ini sangat berpengaruh pada perekonomian termasuk dunia Perbankan, dalam keadaan seperti ini maka pihak Perbankan diharapkan lebih berhati-hati di dalam menjalankan setiap kegiatan usahanya yang di sebut prudensial banking.Pihak Bank wajib mempraktekkan prinsip kehati-hatian dan prudensial bangking ini secara ketat untuk memitigasi resiko kerugian Bank yaitu Bank harus berhati-hati dalam memilih bekerjasama dengan Developer, dan harus memilih Developer yang sudah berpengalaman dan terpecaya.

Pihak Perbankan ketika berhubungan dengan factor eksternal terkait dengan kondisi ekonomi maka ketika Perbankan akan membuat kontrak dengan Developer, pihak Bank dapat meminta jaminan lain guna menjamin kewajiban Developer untuk membeli kembali, misalnya jaminan kerjasama dapat didukung pada asset pemegang sahamnya untuk diikat dengan jaminan kebendaan, jaminan pemegang saham dari si pengembang tersebut untuk menjamin kalau Debitur wanprestasi, atau disertai corporate guarantee atau bank guarantee. Menurut penulis dalam kondisi pandemic covid-19 saat ini untuk menghindari kredit macet yang itu akan memperburuk kondisi kredibilitas Perbankan maka pihak Perbankan dan pihak Developer dapat diberikan kebebasan untuk dapat melakukan rescheduling, restructuring dan rekonditioning.

Pelaksanaan reschedule, restructur dan recondition dapat dilakukan penyesuaian syarat-syarat perjanjian dengan keadaan sekarang. Pelaksanaan reschedule, restructur dan recondition solusi sehingga bisnisnya tetap lancar dan itu berlaku bagi semua pihak baik antara Bank dengan Developer, Bank dengan Konsumen dan antara Developer dengan Konsumen, semua jenis kontraknya perlu dilakukan penyesuaian.

\section{Motivasi dan Kepastian Hukum Payment Guarantee dalam Kontrak}

Motivasi dan Kepastian hukum Payment Guarantee merupakan norma dari regulasi tentang jaminan yaitu norma hukum yang mengatur serta menjamin hubungan antara Pemberi jaminan (Debitur) dan Penerima jaminan (Kreditor) sebagai akibat pembebanan suatu utang tertentu (kredit) dengan suatu jaminan (benda atau orang tertentu).

Dalam praktik Perbankan, khususnya dalam proses Kredit Kepemilikan Rumah (KPR), perjanjian Buy Back Guarantee adalah strategi hukum yang 
ditempuh oleh Bank agar Bank terhindar dari risiko kredit dan risiko hukum. Terdapat beberapa kondisi khusus ketika Bank menggunakan perjanjian Buy Back Guarantee kepada pihak ketiga (dalam hal ini adalah Developer), antara lain ketika Perjanjian Kredit antara Debitur dan Kreditur dengan jaminan kebendaan yang belum bisa di lakukan proses pengikatan jaminan. ${ }^{13}$

Bagi Perbankan memahami isi kontrak merupakan suatu keniscayaan, dan adanya keseimbangan kedudukan para pihak dalam berkontrak menurut penulis merupakan suatu hal yang penting dalam perjanjian pada perbankan syariah, karena dalam konsepsi hukum Islam suatu akad berbicara nilai (value). Nilai yang dimaksud adalah muamalah yang bernilai ibadah jika dilakukan dengan kejujuran ${ }^{14}$.

Beberapa pasal dalam KUHPerdata dapat ditemukan norma yang mengatur tentang jaminan secara umum, yaitu dapat dilihat dalam pasal 1131 dan Pasal 1132 KUHPerdata. Dalam Pasal 1131 KUHPerdata disebutkan "Segala barang-barang bergerak dan tak bergerak milik Debitur, baik yang sudah ada maupun yang akan ada, menjadi jaminan untuk perikatan-perikatan perorangan Debitur itu." Dengan demikian menurut ketentuan tersebut, segala harta kekayaan seseorang otomatis menjadi jaminan atas utang yang telah dibuat.

Sebagaimana diketahui unsur esensial dari kredit Bank adalah adanya kepercayaan dari Bank sebagai Kreditor terhadap Nasabah Peminjam sebagai Debitur. Kepercayaan tersebut timbul karena dipenuhinya segala ketentuan dan persyaratan untuk memperoleh kredit Bank oleh Debitur antara lain: jelasnya tujuan pemberian kredit, adanya benda jaminan atau agunan dan lain-lainya. ${ }^{15}$ Terkait barang yang akan menjadi jaminan Pasal 1132 KUHPerdata menyebutkan barang-barang itu menjadi jaminan bersama bagi semua kreditur terhadapnya, hasil penjualan barang-barang itu dibagi menurut perbandingan utang masing-masing kecuali bila di antara para Kreditur ada alasan-alasan sah untuk didahulukan.

Pemberian jaminan dalam Perjanjian Kredit diharuskan dalam dunia Perbankan konvensional karena pada dasarnya, sumber dana yang disalurkan

13 Dona Budi Kharisma, Buy Back Gurantee dan Perkembangan Hukum Jaminan Kontemporer Indonesia, Jurnal Privat Law, 3,2 (2015)

${ }^{14}$ Taufik Kurrohman, "Peran Dewan Pengawas Syariah Terhadap Syariah Compliance Pada Perbankan Syariah." Jurnal Surya Kencana Satu: Dinamika Masalah Hukum dan Keadilan 8.2 (2017): 56.

${ }^{15}$ Hermansyah, Hukum Perbankan Nasional Indonesia, Predana Media Group, Jakarta, 2006, hlm. 58. 
berasal dari tabungan masyarakat. Dengan demikian, dana kredit yang disalurkan harus dilakukan secara hati-hati (prudent). ${ }^{16}$

Menurut hemat penulis berawal dari konsep tentang jaminan secara umum, di atas maka apabila dilihat dari jaminan secara umum yang pada intinya memiliki 2 konsep yaitu jaminan yang bersifat umum dan jaminan yang bersifat khusus. Pada klasifikasi jaminan umum berlaku bagi semua Kreditur dan semua aset atau harta benda debitur artinya tidak ada Kreditur yang di dahulukan dan jaminan umum ini ada secara otomatis berdasar ketentuan undang-undang yaitu pasal 1131 KUHPerdata, jadi jaminan umum ini ada berdasarkan ketentuan undang-undang (operation of law), artinya jaminan ini otomatis ada ketika orang atau badan hukum membuat perikatan dan secara otomatis asetnya menjadi jaminan hukum sebagaimana dimaksud pada pasal 1131 sampai 1132 KUHPerdata.

Berbeda dengan jaminan umum apabila Kemudian masuk jaminan khusus, maka jaminan khusus dapat dibagi menjadi 2 (dua), yaitu klasifikasi jaminan yang terjadi berdasarkan ketentuan Undang-Undang dan disebabkan adanya klausula yang perjanjikan para pihak dalam kontraknya, hal ini terkait benda tertentu atau orang di tunjuk sebagai penjamin,selanjutnya jaminan yang terjadi karena Undang-Undang dibagi menjadi 2 (dua) yaitu Hak Privilege atauhak istimewa dan Hak Retensi atau penahanan benda kedua hak tersebut memiliki kekuatan hukum secara otomatis karena ketentuan Undang-Undang. Jaminan khusus yang lahir dari perjanjian atau yang diperjanjikan di bagi dalam dua bentuk ,yaitu yang berupa jaminan berbentuk khusus dan berisfat kebendaan dan jaminan khusus bersifat perorangan.Terkait bentuk Jaminan khusus kebendaan memiliki karakteristik yang ada dalam hak-hak kebendaan, karena jaminan bersifat khusus.

Sementara jaminan khusus perorangan hanya di tunjuk orang yang secara khusus untuk menjamin kewajiban Debitur. orang yang dimaksud adalah orang dalam arti alamiah manusia, bisa badan hukum (cooporate garantie), tetapi terkait jaminan perorangan menurut hemat penulis sebenarnya bila memilih jaminan khusus perorangan karena dasarnya perjanjian maka berlakulah azas kebebasan berkontrak, Jadi tidak terbatas ke jaminan penanggungan yang nantinya akan penulis kaitkan dengan Payment Guarantee.

Secara khusus untuk jaminan kebendaan karena keberadaanya diatur dalam ketentuan undang-undang sebagaiman kita ketahui dapat berupa jaminan fidusia, gadai, hipotik, dan hak tanggungan maka jelas dan tegas

${ }^{16}$ Irma Devita Purnamasari, Hukum Jaminan Perbankan, PT.Mizan Pustaka, Jakarta, 2011, hlm.18. 
mekanisme eksekusinya, walaupun dalam perkembangan terakhir banyak timbul masalah baru.

Ketika berbicara jaminan perorangan maka karena sebagai penjamin yang di tunjuk itu orang atau subjek hukum sebagai penjaminnya maka tidak ada benda khusus yang dijadikan jaminan sehingga dapat meliputi semua aset penjamin. Payment Guarantee atau Buyback Guarantee (jaminan pembelian kembali) yang biasa di kenal masyarakat masuk dalam jaminan khusus perorangan karena dasarnya adalah perjanjian, namun kateristiknya berbeda dengan jaminan penaggungan hutang yang selama ini kita pahami, dan hal ini perlu dipahami karena apabila dikaji dari segi jaminannya bukan ditekankan pada jaminan terhadap pembayaran hutang tetapi berupa jaminan untuk membeli kembali aset yang telah di jual, dan di sini letak perbedaaanya dengan jaminan penanggungan hutang, karena dalam jaminan penanggungan hutang maka yang dijaminkan adalah hutangnya si Debitur.

Dalam Buyback Guarantee yang di jaminkan adalah hutangnya si Debitur yang di jamin dalam hal ini berupa jaminan pembelian kembali obek jual beli, artinya yang di jaminkan dalam perjanjianya adalah membeli kembali barang yang sudah di jual, walaupun pada akhirnya hasil penjualannya untuk melunasi kewajiban Debitur, tapi focus jaminan hutang bukanlah hal yang utama karena jaminan yang utama adalah membeli kembali aset yang sudah di jual.

Jaminan yang utama perjanjian antara Bank dan Developer adalah membeli kembali aset yang sudah di jual maka dapat disimpulkan Buyback Guarantee memiliki hubungan hukum yang bersifar persfektif yaitu hubungan hukumnya terkait antara Bank dengan Developer; antara Bank dengan Debitur; dan antara Developer dengan Konsumen jadi hubungan hukumnya seperti itu. Letak Jaminan pembelian kembali ini adanya di hubungan antara Bank dan Developer. ${ }^{17}$

Pada awal inisiatif dan keinginan untuk dilakukanya jaminan pembelian kembali adalah berasal dari Developer untuk mencari dan meyakinkan Bank dalam menyediakan fasilitas KPR, agar supaya Developer dapat membangun perumahan atau apartemen yang nantinya akan dibeli Konsumen,tetapi pada keadaan selanjutnya ternyata inisiatif jaminan pembelian kembali tidak hanya datang dari Developer tetapi dari pihak Bank dengan sendirinya.

Pada Salah satu karakter Payment Guarantee dalam perjanjian Untuk menjamin pelaksanaan Perjanjian Kerjasama dengan waktu yang tidak lama sekitar 3 sampai 6 bulan, karena umumnya jaminan pembelian digunakan untuk menjamin kalau Debiturnya wanprestasi sementara objek jual beli belum bisa

\footnotetext{
${ }^{17}$ Wawancara dengan DR. Akhmad Budi Cahyono,S.H.,M.H., Dosen Hukum Perdata Universitas Indonesia, Kamis, 16 Juli 2020.
} 
di ikat dengan jaminan, misalnya tanahnya masih dalam konsep sertifikat induk, sehingga belum di pecah dan biasanya bentuknya masih HGB atau Hak Guna Bangunan, karena HGB belum di pecah maka belum bisa dibuatkan Akta Jual Belinya, sehingga belum bisa di ikat dengan jaminan Hak Tanggungan dan inilah yang menjadi latar belakang munculnya instrument Buyback Guarantee atau Payment Guarantee.

Pada kenyataannya Payment Guarantee cukup relevan dalam Perjanjian Kerjasama dalam jangka waktu pendek tersebut karena apabila sudah ada atau sudah dapat di ikat jaminan relatif pihak Bank sudah aman karena sudah diikat dengan Hak Tanggungan. Keberadaan Payment Guarantee digunakan dalam Perjanjian Kerjasama pada umumnya terjadi karena sertifikatnya belum di pecah, dan ternyata rumah belum di bangun atau pembangunan perumahan belum selesai,apabila berbicara di Undang-Undang perumahan syarat keterbangunan hanya 20\%, jadi sudah bisa dipasarkan, dengan syarat keterbangunan 20\% itu pun banyak Developer atau Pengembang yang mengambil resiko, contohnya Meikarta belum 20\% pihak developer sudah berani memasarkan.

Konsep jaminan perorangan sifatnya adalah hak perorangan bukan hak kebendaan jadi relatif lebih beresiko di bandingkan jaminan kebendaan, oleh karenanya maka memang diperlukan kehati-hatian dari pihak Perbankan khususnya dalam memilih Partner atau Developer yang akan menjalin kerjasama dengan Bank dalam pemberian fasilitas KPR, dan biasanya Bank akan melihat track record Developer.

Kaitannya kehati-hatian dari pihak Perbankan khususnya dalam memilih Partner atau Developer yang akan menjalin kerjasama dengan Bank dalam pemberian fasilitas KPR kedepannya terutama dalam kondisi bencana yang masuk dalam peristiwa di luar kesalahan para pihak (overmark) para pihak dapat melakukan rescheduling, restructuring dan rekonditioning, dengan adanya rescheduling, retsructuring dan rekonditioning ini tentunya Debitur tidak bisa dikatakan wanprestasi karena ada penundaan pembayaran kewajiban, misalnya yang harusnya sudah jatuh tempo tapi itu di undur.

\section{Simpulan}

Payment Guarantee jelas ada mamfaatnya bagi Perbankan dan pihak Develover karena dengan adanya jaminan pembelian kembali setidaknya ada ikatan antar pihak Bank dan Developer secara khusus, justru apabila tidak ada Payment Guarantee kurang memberikan kepastian hukum. Motivasi Bank menggunakan instrumen Payment Guarantee dalam konsep untuk memitigasi resiko kredit macet yang dapat merugikan Perbankan, konsekuensinya harus ada ketentuan khusus yang mengatur mengenai perjanjian Payment 
Guarantee/ Buyback Guarantee ini, ikatan secara khusus antara Bank dan Developer sehingga lebih memberikan kepastian hukum.

\section{Saran}

Perlu di atur dalam ketentuan undang-undang tidak hanya jaminan kebendaan saja tetapi semua jenis seluruh transaksi yang di ikat dengan jaminan termasuk pembelian kembali agar lebih memberikan kepastian hukum bagi para pihak. Perlu adanya kajian lebih lanjut secara akademis terkait kehati-hatian dari pihak Perbankan khususnya dalam memilih Partner, atau Developer yang akan menjalin kerjasama dengan Bank dalam pemberian fasilitas KPR kedepannya para pihak dapat melakukan reschedul, restructur dan recondition.

\section{Daftar Pustaka}

Agus Yudha Hernoko, Hukum Perjanjian Asas Proporsionalitas Dalam Kontrak Komersial, Pernada Media Group, Jalarta, 2014.

Kusumo Hamidjojo, Perbandingan Hukum Kontrak, Mandar Maju, Budiono Bandung, 2019.

E. Fernando M. Manullang, Legisme, Legalitas dan Kepastian Hukum, Prenada Media, Jakarta, 2019.

Hermansyah, Hukum Perbankan Nasional Indonesia, Predana Media Group, Jakarta, 2006.

Irma Devita Purnamasari, Hukum Jaminan Perbankan, PT. Mizan Pustaka, Jakarta, 2011.

I.Ketut Oka Setiawan, Hukum Pendaftaran Tanah dan Hak Tanggungan, Sinar Grafika, Jakarta, 2019.

Jimly Asshiddiqie, Pengantar Hukum Tata Negara, Rajawali Pers, Jakarta, 2016.

Racmadi Usman, Hukum Jaminan Keperdataan, SinarGrafika,Jakarta, 2016.

Sentosa Sembiring,Hukum Perbankan Edisi Revisi,Mandar Maju,Bandung, 2012.

Subekti.R, Kitab Undang-Undang Hukum Perdata, Jakarta, Pradnya Paramita, 1995. 
Jurnal

Dona Budi Kharisma, Buy Back Gurantee dan Perkembangan Hukum Jaminan Kontemporer Indonesia, , Jurnal Privat Law, 3,2 (2015).

Kurrohman, Taufik. "Peran Dewan Pengawas Syariah Terhadap Syariah Compliance Pada Perbankan Syariah." Jurnal Surya Kencana Satu: Dinamika MasalahHukum danKeadilan 8.2 (2017): 56.

Siti Nurwullan, Hendrik Fasco Siregar, Frieda Fania, Aspek Yuridis Perbankan sebagai Penyalur Kredit Persfektif Asas Konsesnsualime dalam Berkontrak, Jurnal Pamulang Law Review, 3.8 (2020).

Nurwullan, Siti, and Hendrik Fasco Siregar. "Asas Konsensualisme Dalam Penambahan Klausula Kontrak Berdasarkan Prinsip Itikad Baik." PROCEEDINGS. Vol. 1. No. 1. (2020).

Yandri Radhi Anadi, Kekuatan Hukum Akta Buy Back Guarantee dengan Kuasa Menjual Bagi Pihak Developer, Jurnal Hukum dan Kenotariatan,31,2,(2019).

\section{Peraturan Perundang-Undangan}

Undang-Undang Nomor 10 Tahun 1998 Tentang Perubahan Atas Undang-Undang Nomor 7 Tahun 1992 Tentang Perbankan

Kamus Besar Bahasa Indonesia, Pusat Bahasa Indonesia, edisi ke 4, Departemen Pendidikan Nasional, PT.Gramedia Pustaka Utama, Jakarta 2008. 